\title{
Legal Status of Surface Waters-Comparative Study on the Example of Lakes
}

\author{
Michał Pietkiewicz ${ }^{1}\left(\mathbb{D}\right.$, Anna Klimach ${ }^{2, *(1)}$ and Marek Ogryzek ${ }^{2}(\mathbb{C}$ \\ 1 Faculty of Law and Administration, Department of International Public Law, University of Warmia and \\ Mazury in Olsztyn, Warszawska street 98 10-719 Olsztyn, Poland; michal.pietkiewicz@uwm.edu.pl \\ 2 Faculty of Geoengineering, Department of Land Management and Geographic Information Systems, \\ University of Warmia and Mazury in Olsztyn, Prawochenskiego street 15, 10-720 Olsztyn, Poland; \\ marek.ogryzek@uwm.edu.pl \\ * Correspondence: anna.klimach@uwm.edu.pl
}

Received: 19 December 2019; Accepted: 20 January 2020; Published: 23 January 2020

\begin{abstract}
Water laws in post-Soviet countries have developed in vastly different ways since each state became entitled to choose its own method of regulating inland water ownership. This article analyzes the Russian Federation and selected post-Soviet states' legal systems related to ownership of surface waters, and assesses the possibility of legal transactions of lakes and other land areas covered by surface water. The research initially centers on establishing whether lakes are owned by the state or by the county, if a lake can be subject to sale to a private person or enterprise and finally examines the different approaches of post-Soviet countries to their surface water use. In achieving these objectives, the article analyzes water law in the Russian Federation, Belarus, Ukraine and Kazakhstan. It then identifies how water ownership is regulated in these countries and compares this with United Nations assumptions of surface water ownership as a Sustainable Development Goal. Finally, the results establish that countries from the same "block" regulate water ownership similarly, and that combined regulations could enhance future implementation of international standards.
\end{abstract}

Keywords: water law; surface waters; post-Soviet States

\section{Introduction}

The current water laws in post-Soviet states have resulted from the logical development of their national legal systems, targeted to satisfy their primary economic needs for water use and respond to present environmental challenges [1,2]. The existing water laws cover dynamic social relationships in the study, use, transformation and protection of water bodies. There is presently a mixed method in regulating water law. This is characterized by techniques applicable to both public and private law, and it predetermines power, the submission procedures for water use permits and the equality and independence of water-use agreements [3].

The majority of theorists in water law primarily concentrate on permission under civil law, regulatory direction in administrative law and prohibition under criminal law [4]. While prohibition and criminal sanction is already emphasized in current water codes, environmental protection must be addressed in all emerging water laws [1]. Although there are currently no specialized regulatory methods for water law in the former USSR republics, it can be assessed as a sub-branch of environmental law which is recognized in legal literature and includes natural resources and environmental law [5].

Water laws regulate state water relationships, and this study supplies a comparative analysis of water legislation provisions in several post-Soviet countries to establish the legal status of surface waters in lakes and their surrounds. The greatest challenges in this research are to determine state or county lake ownership and whether lakes can be subject to private contracts and sale. 
Discussion of this issue commences with defining water ownership and individual legal regulations in countries before the USSR collapse. Firstly, the 1918 decree abolished all ownership rights to land, subsoil, water, forests and livestock and transferred them without direct or indirect compensation to the entire "working population" [6]. Here, Article 6 of the Soviet Constitution indicated that water belonged to the entire nation [7]. The "principles of civil legislation and union republics" were then approved in 1961, and these provided regulations related to social and personal property which were binding on all union republics [8]. There was therefore a long period where land and water in Soviet countries was owned by the entire "working population". Changes in the Soviet Union and the emergence of individual countries, however, caused legislation changes and it is most important to establish how the different changes in our selected countries originated from one legal ideology. The prime objective was to determine if these countries regulate lake ownership differently and then explore the possible legalities of marketing them.

The Russian Federation, Belarus, Ukraine and Kazakhstan selected entities are all members of the United Nations, and sustained media attention rapidly brings global knowledge of their adopted solutions to these issues and the impact of their implementation on Sustainable Development Goals. World countries therefore strive to achieve common goals to ensure poverty eradication, using strategies that improve health and education, reduce inequalities and stimulate economic growth while fighting climate change and working to protect the world's oceans and forests [9].

\section{Materials and Methods}

Research was conducted on the selected Russian Federation, Belarus, Ukraine and Kazakhstan post-Soviet states. Of the fifteen emerging USSR countries, the three largest (Russian Federation, Ukraine and Kazakhstan) were selected for investigation, and Belarus was added for comparison purposes. This comparison will determine if the much smaller Belarus country has adopted different regulations to their much larger counterparts in water ownership and trade. A further criterion for theses countries' selection is that none are European Union members or candidates, and this enables identification of how countries in 'one circle' made changes in their legislation without international interference. In addition, it is established that the surface waters in these countries form only $2 \%$ of land surface areas [10], and similar studies have already been conducted in countries such as Uzbekistan [11].

The initial research herein examines if the selected USSR countries can voluntarily shape legal regulations for surface water ownership and, if so, how this regulation is accomplished. Moreover, it is acknowledged that these countries continue updating their legislation, and our research therefore examines the conditions and circumstances causing different formulations of their legal concepts and priorities. Finally, common approaches to state and municipal ownership of water bodies are then discussed and compared.

Herein, we applied comparative law methodology to identify the strengths and weaknesses of the selected countries' legal systems [12] and we then compare their legal acts regarding water properties and concepts.

The initial task was to analyze the legal texts and civil codes for regulations in land and water ownership and then compare specific water regulations imposed in individual state water codes. The most difficult challenge was to identify whether trading in land covered with inland surface waters is permissible in these countries and, if so, to what extent. This problem is compounded by knowledge that all citizens in a country are allowed to use surface water, and it therefore requires legal certainty whether water use is granted for all waters or only for those in the public domain, and most importantly, if these waters can become private property.

Finally, both "rent" and "lease" can be used in English terminology, but here we employ "rent" to prevent translational ambiguity. 


\section{Results}

\subsection{Comparison of the Legal Status of Lakes in the Russian Federation and Former USSR Republics-Russia}

This study identifies the provisions of the Russian Federation water legislation. The modern legal regulations for water body ownership and their use in the Russian Federation was formed in 2006 following adoption of the new Russian Federation Water Code [13]. Although the expert community is constantly debating the application of these standards, granting ownership to various types of water bodies or their parts occurs in practice, and this includes widespread grants to incompetent authorities for the right to use them and to conclude lake rental agreements [14].

Part 1 of Article 8 of the Russian Federation Water Code stipulates that water bodies, except ponds and flooded quarries, are under federal ownership. Part 2 of this Article then regulates that ponds and flooded quarry ownership depends on the land ownership, and this can be under state, municipal or private ownership. Moreover, pond and flooded quarry ownership arises and ceases simultaneously with the occurrence and termination of the right to the land on which these water bodies are located. However, other legal Acts, including federal laws and Acts of Entities forming the Russian Federation, combine with, and may supersede, the Russian Federation Water Code in regulating these water management aspects $[15,16]$.

This Russian Federation legal regulation of ownership of water bodies is based on the principle of a basin approach. This provides that all natural water bodies are hydraulically connected within the same water basin, and therefore cannot be differentiated as objects of ownership [17]. While this definition of ownership eliminated many problems that existed in the area of delimitation of the property of both the Federation and its constituent entities before adoption of the Russian Federation Water Code in 2006, many unresolved issues remain with regard to anthropogenic water bodies.

This Water Code does not define "pond", "flooded quarry" or "lake" concepts, and it is therefore assumed that the term "lake" is included in the more general legal category of "water body". Article 1 of the Water Code then defines that "a water body is a natural or artificial body of water, a watercourse or other object, the permanent or temporary concentration of water which has the characteristic forms and signs of the water regime". It then continues that "water resources" are "surface and groundwater that are in water bodies and are used or can be used."

Finally, Article 5, Paragraph 2 of the Russian Federation Water Code classifies lakes as surface water bodies, and Article 6 states all the following; "surface water bodies owned by state or municipal property are public water bodies" (they may not be sold in private sector), and "every citizen has the right to have access to public water bodies and use them free of charge for personal and domestic needs" and "a strip of land along the coastline (border of a water body) of a public water body (coastal strip) is intended for general use. The width of the coastal strip of public water bodies is twenty meters", "every person has the right to use (without using mechanical vehicles) the coastal strip of public water bodies for movement and stay near them, including for recreational and sport fishing and the mooring of floating equipment". These Civil Code provisions therefore clearly indicate that everyone can be not only at the water but also at the area surrounding the water. Most importantly, the provision mentions "surface water bodies", so it must be assumed that access is to both rivers and lakes.

As previously mentioned, the main focus of this research is on ownership and access to lakes. Ownership is a fundamental concept of legal science and practice and, far in the past, Roman lawyers understood property as the most complete domination of a thing, although only over the course of centuries. European legal consensus then began to understand property right as the well-known triad of possession, use and disposal. These entail physical possession, the ability to exploit and derive useful effect from owned objects and the ability to determine the object's legal fate through sale or rent [18-21].

This view of property is shared by Russian legal theory and it is reflected in Russian law. Articles 209-211 of the Russian Federation Civil Code [22] stipulate that the owner has the right to own, 
use and dispose of his property, as well as bear the burden of maintenance and the risk of property destruction [23]. In addition or contrast, however, Articles 129 and 209 establish "environmental priorities", where free possession, use, and disposal of land and other natural resources is limited by requirements not to harm the environment [24]. Article 129 further defines that land and other natural resources may be alienated and transferred from one person to another in such a way and extent that their circulation is permitted by the laws on land and other natural resources. Thus, the application of the institution of property law to land, subsoil, forests, water and wildlife natural resources has its own fundamental features [25].

Further, the content of water body ownership is determined by both civil and water legislation. A characteristic water legislation feature of water body ownership is the incomplete application of the concept of "ownership" to water bodies, because the water concentrated in them is in a state of continuous movement and water exchange. A further feature of this ownership is prohibition of alienation of water bodies, except for ponds and flooded quarries [26]. It is therefore emphasized that ownership under Russian Civil Law is treated in precisely the same manner as in countries with roots in Roman law.

The owner of a lake can own, use and dispose of the property, with the only assumption that the state or municipality is the owner of the lake, but this state or municipal ownership does not preclude agreements that the waters will be made available to other entities. Further, Article 11 of the Russian Federation Water Code designates that, depending on the purpose of water use, the right to use water bodies covered by state or municipal property can be based either on a water-use agreement or on a decision on provision of a water body for use. The water code also provides that certain types of water use may be carried out without the execution of either of these documents [27].

In addition, the authority to conclude such agreements or to provide a decision is invested in the Federal Agency for Water Resources (FAWR) and its regional bodies. A formal contract follows an initial water-use agreement, and therein the first party, such as the state authority or local government, is obliged to provide the second party with a water body or part of it for use, for a fee. The water use contract is thus regulated by the Russian Federation Water Code, and simultaneously, unless otherwise specified or it contradicts the essence of the water use contract, the rent provisions are applied in conformation with Article 12 of the Russian Federation Civil Code. Furthermore, water bodies can also be contracted for water drainage, hydro-electricity and recreational purposes. In contrast to a water use contract, the provision of water bodies based on a decision is administrative in nature [28], and Articles 43-54 of the Russian Federation Water Code list the purposes of water use.

Authors consider that it is impossible to rent a lake as a separate land plot because the Russian Federation Land Code does not recognize that land covered by surface waters forms a land plot $[29,30]$. It is therefore legally impossible to form a land plot on a lake and rent it out or to register the lake as a property for rent. In contradistinction, lake rent for recreational purposes, for example, is approached through a water-use agreement, and it is possible in this special instance to arrange water use for both the entire lake and a rental plot of the lake. However, it is also important to realize that after the water use is registered it is almost impossible to protect it.

When rented water use of a lake is envisaged, it is necessary to contact the territorial division of the Federal Agency for Water Resources [31] or the regional authority authorized to dispose of water bodies. The initial steps should include advice from authority specialists, and prior approval then enables the applicant to submit the stipulated documents required to conclude the water-use agreement. Information on rented water-use agreement facilities is contained in the state water register (SWR) [32], and it is first necessary to submit a request to the FAWR territorial body on a special form prior to requesting SWR information on whether the lake is available for rent [33]. This routine is necessary because it is not always possible to unambiguously determine from the water registry if a water body is rented under a water-use agreement [34].

Many lakes have a very large area and therefore geodetic work must first be conducted to establish if the requested part of the water area is available for rent. The respective boundaries are then delineated 
in map format. Although it is relatively easy to rent a $20 \mathrm{~m}$ public area of lake shore, especially if water use is already granted, it is impossible to obtain any ownership because lakes and their $20 \mathrm{~m}$ shores are public property.

In order to obtain land rental it is essential to employ a cadastral engineer before presenting the scheme on the territorial cadastral plan to the regional administration land department. The land in the rental application will then be auctioned and must be bid for. In practice, acquired ownership of Russian land around lakes formally remains accessible to the population. However, access to it requires passage through the owner's property, and the landowner automatically obtains actual access to the lake within the rented land.

There can, however, be some legal conundrum, because although the owner takes the lake itself for rent and pays the taxes on profits from its use and no questions generally arise from the authorities, there may be strong public opposition where local inhabitants unite in defending their right to access the lake. Legal proceedings can then follow and the outcome is judicial.

\subsection{Other States}

\subsubsection{Belarus}

Although the Republic of Belarus has no concept of "lake" in its Water Code [35], the term "water body" is present, and this covers the "concentration of water in artificial or natural depressions of the earth's surface or in the bowels, which has certain boundaries, volume and signs of a hydrological or groundwater regime". In addition, Article 1 of the Republic of Belarus Water Code states that "water resources" refers to "surface and groundwater" that is used or can be used in economic and other activities" [36]. Article 5, Paragraph 4 of the code then indicates that lakes are included in natural bodies of water under the classification of surface water bodies, and Article 8 declares that: "All waters located on the territory of the Republic of Belarus constitute the exclusive property of the state. The right of ownership to the extracted (withdrawn) water belongs to the water user who has carried out its extraction (withdrawal) legally, unless otherwise provided by legislative acts".

The Water Code then declares that the state administration in the field of water protection and use is carried out by the President of the Republic of Belarus, the Council of Ministers of the Republic of Belarus, the Ministry of Natural Resources and Environmental Protection of the Republic of Belarus, the Ministry of Health of the Republic of Belarus, the Ministry on emergency situations of the Republic of Belarus, local Councils of Deputies, executive and administrative bodies, as well as other state bodies in the extent of their competence. Moreover, surface water bodies can be rented for fish farming under rent agreements concluded by local executive and administrative bodies on the basis of decisions taken by local Councils of Deputies. This clearly defines that surface water bodies, which include lakes in the "natural bodies of water" terminology, can only be rented in the Republic of Belarus and they cannot be privately owned.

\subsubsection{Ukraine}

The term "lake" is defined in Article 1 of the Ukraine Water Code as "a natural depression of land filled with fresh or salt waters" [37]. Article 5 then states that lakes are "surface waters within the water bodies' category and that they have national importance" and this is followed by the Article 6 statement that: "waters (water bodies) are exclusively the property of the people of Ukraine and are provided only for their use. The people of Ukraine exercise ownership of the water (water bodies) through the Verkhovna Rada of Ukraine, the Verkhovna Rada of the Autonomous Republic of Crimea and local Councils; and that separate powers regarding the management of waters (water bodies) may be granted to the relevant bodies of state executive power" [38].

Article 42 of the Ukraine Water Code adds that "water users in Ukraine can be enterprises, institutions, organizations and citizens of Ukraine, as well as foreigners and stateless persons and foreign legal entities". Thus, in Ukraine, as in Russia and Belarus, the use of surface waters, as in 
lakes, is allowed in a water-use agreement which is a contract on rental conditions under Article 51. Moreover, all water bodies are the property of the Ukraine people and they cannot be subject to sale. However, changes are now being processed under Ukraine law to bring water legislation closer to the European Union and its Directives [39]. Finally, the literature explored in this research confirms Ukraine's need to introduce and harmonize the terms related to waters in both their definition and national ecological elements [40].

\subsubsection{Kazakhstan}

Kazakhstan has "The Republic of Kazakhstan Water Code" [41]. Article 4 therein states that "the water fund of the Republic of Kazakhstan includes the totality of all water bodies within the territory of the Republic of Kazakhstan included or to be included in the state water cadaster". Although there is no separate definition of "lake" and "surface water" concepts, Article 5 notes that "water bodies of the Republic of Kazakhstan include water concentrations in land surface reliefs and bowels of the earth that have boundaries, volume and water regime". These therefore include lakes which are 'surface water bodies'. Article 6 then defines water resources as "reserves of surface and groundwater concentrated in water bodies that are or can be used" and Article 8 discloses the following ownership of the Kazakhstan water fund: "The water fund of the Republic of Kazakhstan is in exclusive state ownership, and the right of possession, use and disposal of the water fund is exercised by the Government of the Republic of Kazakhstan" [42].

Article 22 then specifies that "the right to use water bodies is granted to individuals and legal entities in the manner of special, separate or shared use established by the Water Code of Kazakhstan." Water bodies are therefore provided to individuals and legal entities for the following rights: (1) short-term use; (2) long-term use. These terms are specified as follows: the right to short-term use is granted for a period of up to five years, the right to long-term use is granted for a period of five to forty-nine years. Moreover, individuals and legal entities to whom water bodies are provided for use cannot dispose of the right to use the water body [43].

It is therefore concluded that it is impossible to obtain ownership of lakes in the Republic of Kazakhstan; these can only be rented under a water-use agreement. This is a contract in its nature and there is no other possibility of lake ownership.

\subsection{Summary of the Countries' Regulations Analyzed}

Analysis of the selected countries' legislation has revealed similarities. There is no legal definition of lakes, the countries have regulated the legal status of waters similarly, their surface waters remain state property and renting is the only the possibility. It is therefore important that the exercise of rights for maintenance and access to water remains in state hands, and permission to rent a lake has become good practice because state water for shared citizen use can also be used for other purposes.

Table 1 reveals that the surveyed countries lack definitions of individual surface water types. Moreover, waters flow through one or more countries, so it is necessary to clearly indicate what type of water it is, so that this will enhance possible joint ventures and prevent international repercussions. The following discussion indicates the tasks where determining the legal status of surface waters is important not only for the country where the waters occur but also for contiguous countries and international institutions. 
Table 1. Comparison of all Former USSR Republic Water Legislation Features.

\begin{tabular}{|c|c|c|c|c|}
\hline Country & $\begin{array}{l}\text { Definitions (Lake, } \\
\text { Water Resources, } \\
\text { Water Body) }\end{array}$ & $\begin{array}{l}\text { Ownership } \\
\text { of the Lakes }\end{array}$ & $\begin{array}{l}\text { Possibility to } \\
\text { Buy a Lake }\end{array}$ & $\begin{array}{c}\text { Administrative Body that Governs } \\
\text { The Lakes }\end{array}$ \\
\hline Russia & $\begin{array}{l}\text { Water resources, } \\
\text { water body }\end{array}$ & $\begin{array}{l}\text { State or } \\
\text { municipal } \\
\text { property }\end{array}$ & Rental only & $\begin{array}{l}\text { Bodies of state power of the Russian } \\
\text { Federation, bodies of state power of } \\
\text { the constituent entities of the } \\
\text { Russian Federation, bodies of local } \\
\text { self-government within the limits of } \\
\text { their authority established by } \\
\text { regulatory legal acts }\end{array}$ \\
\hline Belarus & $\begin{array}{l}\text { Water resources, } \\
\text { water body }\end{array}$ & $\begin{array}{l}\text { State } \\
\text { property }\end{array}$ & Rental only & $\begin{array}{l}\text { The President of the Republic of } \\
\text { Belarus, the Council of Ministers of } \\
\text { the Republic of Belarus, the } \\
\text { Ministry of Natural Resources and } \\
\text { Environmental Protection of the } \\
\text { Republic of Belarus, the Ministry of } \\
\text { Health of the Republic of Belarus, } \\
\text { the Ministry of Emergency } \\
\text { Situations of the Republic of } \\
\text { Belarus, local Councils of Deputies, } \\
\text { executive and administrative bodies, } \\
\text { as well as other state bodies within } \\
\text { their competence }\end{array}$ \\
\hline Ukraine & $\begin{array}{l}\text { Water resources, } \\
\text { water body }\end{array}$ & $\begin{array}{c}\text { State } \\
\text { property }\end{array}$ & Rental only & $\begin{array}{c}\text { The people of Ukraine exercise } \\
\text { ownership of the water (water } \\
\text { bodies) through the Verkhovna } \\
\text { Rada of Ukraine, the Verkhovna } \\
\text { Rada of the Autonomous Republic } \\
\text { of Crimea and local Councils. } \\
\text { Separate powers regarding the } \\
\text { management of waters (water } \\
\text { bodies) may be granted to the } \\
\text { relevant bodies of state executive } \\
\text { power }\end{array}$ \\
\hline Kazakhstan & $\begin{array}{l}\text { Water resources, } \\
\text { water body }\end{array}$ & $\begin{array}{c}\text { State } \\
\text { property }\end{array}$ & Rental only & $\begin{array}{l}\text { The right of possession, use and } \\
\text { disposal of the water fund is } \\
\text { exercised by the Government of the } \\
\text { Republic of Kazakhstan }\end{array}$ \\
\hline
\end{tabular}

Source: own study.

Finally, literature searches have indicated that transition from the USSR to separate states and development of individual legal frameworks is not always straightforward [44], but these processes are important in shaping legal regulations.

\section{Discussion}

Water is the most bountiful commodity on Earth [45] and it is necessary to determine its legal status. The legal status of flowing surface water is important not only for the state and its citizens who use this water, but also for implementation of both tasks related to water resource management and pressing duties such as Sustainable Development Goals [9]. The United Nations has indicated 17 goals which should be achieved by 2030. These include the following: Goal 6, i.e., clean water and sanitation, and Goal 14, i.e., life below water. In addition, Millennium Development Goals link water to various goals [46].

The following targets are indicated in Goal 6: 
- “6.1 By 2030, achieve universal and equitable access to safe and affordable drinking water for all;

- 6.2 By 2030, achieve access to adequate and equitable sanitation and hygiene for all and end open defecation, paying special attention to the needs of women and girls and those in vulnerable situations;

- 6.3 By 2030, improve water quality by reducing pollution, eliminating dumping and minimizing release of hazardous chemicals and materials, halving the proportion of untreated wastewater and substantially increasing recycling and safe reuse globally;

- 6.4 By 2030, substantially increase water-use efficiency across all sectors and ensure sustainable withdrawals and supply of freshwater to address water scarcity and substantially reduce the number of people suffering from water scarcity;

- $\quad 6.5$ By 2030, implement integrated water resources management at all levels, including through trans-boundary cooperation as appropriate;

- 6.6 By 2020, protect and restore water-related ecosystems, including mountains, forests, wetlands, rivers, aquifers and lakes;

- 6.A By 2030, expand international cooperation and capacity-building support to developing countries in water- and sanitation-related activities and programmes, including water harvesting, desalination, water efficiency, wastewater treatment, recycling and reuse technologies;

- 6.B Support and strengthen the participation of local communities in improving water and sanitation management" [9].

Implementation of targets 6.5 and 6.A requires international cooperation and indication of who has the right to waters so that water resources can be effectively managed. Ensuring cooperation between countries can be difficult where ownership of lakes is differently regulated, and considerations must include private and public water property and the different ways of using waters and making them available.

Additional challenges for water regulation and management are that water is associated with so many human and environmental essentials. These include zero hunger, affordable and clean energy, climate action, life on land [47], the water-energy-food relationship and coordination of all these necessities both within one country and internationally [48-50]. Therefore, difficulties must arise when countries have differently regulated water issues.

The concept of "integrated water resources management" (IWRM) is widely discussed in the literature [50-52]. The Global Water Partnership's definition of IWRM states: "IWRM is a process which promotes the coordinated development and management of water, land and related resources, in order to maximize the resultant economic and social welfare in an equitable manner without compromising the sustainability of vital ecosystems." [53] The UN has indicated 5 principles that should be followed in IWRM: “

1. Basin management;

2. Intersectoral and vertical coordination of water management;

3. Transparency and public participation;

4. Ensure sustainability of water resources use, including the protection of ecosystems;

5. Financial stability of water management and use of economic instruments" [54].

These principles cover many aspects related to waters, especially from elements related to environmental protection [55,56], water necessary for food production and industry [57], and rest and recreation [58]. These principles are implemented to varying degrees in different countries and are often associated with legislative changes. Finally, achievement of Sustainable Development Goals and IWRM can be accomplished more easily when countries that wish to cooperate have similar water regulations. 


\section{Conclusions}

The former republics of the USSR have much in common in water legislation due to their common Soviet past when the general legal regime for regulating water relations was in effect. However, the former USSR republics have begun to update their legislation, and while common approaches on issues of state and municipal ownership of water bodies remain, there are differences in concept wording and law priorities. There is division at the federal, regional and municipal levels in Russia and the unitary states have their state and municipal levels.

The situation with Latvia, Lithuania and Estonia, which became members of the European Union, is somewhat different. Although government decisions on the specifics of the right to ownership and use of water bodies are retained in these states, they are also guided by EU directives for water resource management. This is apparent in the Council of the European Union Directive "On the quality of water intended for human consumption" 98/83/EC of November 3, 1998 [59]. While the EU directives are not primarily concerned with ownership and use of water bodies and concentrate on regulating the quality of drinking water and the ecological status of water bodies, including lakes [60], it would be extremely useful for the Baltic States to develop water codes where they comprehensively and systematically disclose all legal aspects of regulating water relationships.

Public ownership of water involves daily care by competent authorities and organizations, the use of appropriate administrative procedures and contractual and concession mechanisms to ensure the development, rational use and protection of the water fund. It is most important that the legal classification of water bodies rests in the absence of definitions for many types of water bodies. This usually entails the absence of special methods of legal regulation. Here, the former USSR republic legislators should ensure that their surface water body definitions provide uniform and responsible legal application for their rivers, streams, canals, reservoirs, lakes, ponds, quarries, glaciers and snowfields. Moreover, differentiation of the legal regime should consider the natural and anthropogenic origin of these water bodies and their economic significance, because the above water bodies all differ significantly in ecosystem origin, properties and economic purpose [61]. Increased protection of the coastal zone can also prevent damage to fertilization processes from unnecessarily cutting plants and concreting lake shores [62].

The legal regime's differentiation trends in legal norms and water body implementation measures should function to ensure that legal regulation adequately meets practical needs and flexibly considers the different water body indicators and features. Herein, lack of terminology clarity can cause problems in concluding water contracts because there must be unassailable legality that the object of the rental agreement is in fact a lake and that this object can be subject to trading.

In conclusion, implementation of Sustainable Development Goals is difficult because surface waters often move from country to country. While uniform and similar water regulations can have a positive effect on the achievement of these goals set for 2030, conceptual ambiguity and the lack of universal legal object definitions in post-Soviet countries can prevent or delay achieving these goals.

Author Contributions: Conceptualization - M.P. and A.K.; methodology - A.K.; validation - M.P. and A.K.; investigation, - M.P. and A.K.; resources - M.P. and A.K.; writing-original draft preparation - M.P.; writing-review and editing - M.P. and A.K.; visualization - M.O.; supervision - M.O.; funding acquisition - A.K. All authors have read and agreed to the published version of the manuscript.

Funding: This research prepared under the statutory research No. 28.610.020-300.

Conflicts of Interest: The authors declare no conflicts of interest.

\section{References}

1. Szymańska, U.; Zębek, E. Ochrona Środowiska Naturalnego Jako Interdyscyplinarna Dziedzina Wiedzy (Environmental Protection as an Interdisciplinary Field of Knowledge); Wydawnictwo Uniwersytetu Warmińsko-Mazurskiego: Olsztyn, Poland, 2014; p. 211. ISBN 978-83-7299-924-5.

2. Various, C. The Great Russian Encyclopedia, Great Russian; Encyclopedia: Moscow, Russian, 2006; p. 487. 
3. Agafonov, A.V. Water law of Russia: Concept, subject and method of legal regulation, Humanitarian. Socioecon. Soc. Sci. 2016, 6-7, 129.

4. Sorokin, V.D. The Method of Legal Regulation: Theoretical Problems; Legal literature: Moscow, Russian, 1976; pp. 86-96.

5. Kalinin, I.B. Legal Problems of Strengthening Russian Statehood Part 5; Volovich, V.F., Ed.; Tomsk University: Tomsk Oblast, Russia, 2000; pp. 202-206.

6. Hazard, J.N. Soviet Property Law, 30 Cornell L. Rev. 466 (1945). Available online: http://scholarship.law. cornell.edu/clr/vol30/iss4/5 (accessed on 25 October 2019).

7. Berman, H.J. Soviet property in law and in plan, (With Special Reference to Municipal Land and Housing). Available online: https://scholarship.law.upenn.edu/cgi/viewcontent.cgi?article=8801\&context=penn_law_ reviewa (accessed on 25 October 2019).

8. Szczemielinow, P. Zasady ustawodawstwa cywilnego ZSRR i republik związkowych (Principles of civil legislation of the USSR and trade union republics). 1962; Palestra 6/5(53). 55-60.

9. Sustainable Development. Available online: https://www.un.org/sustainabledevelopment/water-andsanitation/ (accessed on 25 October 2019).

10. Kukharchyk, T.I.; Khomich, V.S.; Kakareka, S.V. Study, assessment and problems of management of small urban reservois in Belarus. In Urban Water Management: Science Technology and Service Delivery; Springer: Dordrecht, The Netherlands, 2003. [CrossRef]

11. Abdullaev, I.; Rakhmatullaev, S. Transformation of water management in Central Asia: From State-centric, hydraulic mission to socio-political control. Environ. Earth Sci. 2015, 73, 849-861. [CrossRef]

12. Fang, L. The Methodology of Comparative Law, Asia Pac. L. Rev. 31 1994. Available online: https: //www.tandfonline.com/doi/abs/10.1080/18758444.1994.11788003 (accessed on 25 October 2019).

13. The Water Code of the Russian Federation of 03.06.2006 number 74-FZ, legal system "Consultant Plus". Available online: http://www.consultant.ru/document/cons_doc_LAW_60683/ (accessed on 14 October 2019).

14. Bukreeva, L.M. Legal regime of water use law. Young Sci. 2017, 32, 62-64.

15. Bolgov, M.V.; Demin, A.P.; Shatalova, K.Y. Institutional, Regulatory, and Managerial Aspects of the Development of Transboundary Water Bodies and Streams in Russia. Water Resour. 2016, 43, 711-717. [CrossRef]

16. Tsyrenova, T.B. Governmental management of water resources under intergovernmental interaction between Russia and Mongolia. Extended Abstract of Doctoral (Polit.) Dissertation, Buryatskii State Univ., Chita, Russia, 2011. Available online: http://cheloveknauka.com/gosudarstvennoe-upravlenie-vodnymi-resursamiv-usloviyah-mezhgosudarstvennogo-vzaimodeystviya-rossii-i-mongolii (accessed on 25 October 2019).

17. Molotov, V.S.; Gomboev, B.O.; Zomonova, E.M. Improving the management system in the use, protection and modernization of the water sector of Russia. Terra Humana. 2011, 4, 204.

18. Brasiello, U. Brevi note sul concetto di proprietà, [w:] Studi in memoria di Francesco Ferrara, Milano. 1993; s. 30.

19. Rozwadowski, W. Rzymska koncepcja własności w kulturze prawnej Europy (The Roman concept of ownership in the legal culture of Europe), Zeszyty Prawnicze UKSW 10.1 (2010).

20. Karpov, A.V.; Velichko, A.S. Ownership. Owner's powers in the civil law "Families" of the world: Nature, evolution, modernity. Account. Law 2005, 8, 2-4.

21. Klimach, A.; Bagan-Kurluta, K.; Pietkiewicz, M.; Źróbek, R. Legal Regulations Concerning Access to Public Waters-A Comparative Study. Sustainability 2019, 11, 4578. [CrossRef]

22. Civil Code of the Russian Federation of November 30, 1994 No. 51-FZ. Available online: http://www. consultant.ru/document/cons_doc_LAW_5142/(accessed on 14 October 2019).

23. Raff, M.; Taitslin, A. Comparative perspective on the concept of ownership in Russian law: From the svod zakonov to the 1994 civil code. Rev. Cent. East Eur. Law 2016, 41, 263-341. [CrossRef]

24. Sukhanov, E.A. The right of ownership in the contemporary civil law of Russia. McGill Law J. 1999, 44, 301-326.

25. Sukhanov, Y. The Concept of Ownership in Current Russian Law. Jurid. Int. 2001, 6, 102-107.

26. Ushakov, E.P. Institute of rental relations as a mechanism for sustainable water use in Russia. Property Relat. Russ. Fed. 2012, 11, 57-58.

27. Babanina, Y.V. The right to use water bodies: Analysis of judicial practice, The contours of global transformations: Politics. Econ. Law 2016, 3, 7-8. 
28. Pryazhinskaya, V.G. Methods and solutions to water management problems in the Russian Federation. Local Sustain. Dev. 2013, 8. Available online: http://fsdejournal.ru/node/519 (accessed on 14 October 2019).

29. Floroff, O.; Tiefenbrun, S.W. Land ownership in the Russian federation: Laws and obstacles. Saint Louis Univ. Law J. 1993, 37, 235-270.

30. The Land Code of the Russian Federation of 25.10.2001 No. 136-FZ. Available online: http://www.consultant. ru/document/cons_doc_LAW_33773 (accessed on 14 October 2019).

31. Estabilished by Resolution of Government of the Russian Federation dated 16 June 2004 No. 282 on Approval of the provision about the federal water resources agency. Available online: http://voda.mnr.gov.ru/favr/ statute/ (accessed on 13 October 2019).

32. Which is established by Decree of the Government of the Russian Federation of April 28, 2007 No. 253 “On the procedure for maintaining the state water register", Order of the Ministry of Natural Resources of the Russian Federation of May 29, 2007 No. 138 "On approval of the state water register", Order of the Ministry of Natural Resources of the Russian Federation of August 22, 2007 No. 216 “On approval of the rules for registering state registration with the state water registry of water use agreements, decisions on the provision of water bodies for use, transfer of rights and obligations under water use agreements, termination of water use agreements". Available online: http://base.garant.ru/12153226/ (accessed on 15 October 2019).

33. The cadaster is also online resource. Available online: http://textual.ru/gvr/ (accessed on 13 October 2019).

34. Sokolov, L.I. Cluster Management, Regional Economics and Management: An Electronic Scientific Journal. 1. Available online: https://eee-region.ru/article/3310/ (accessed on 14 October 2019).

35. Water Code of the Republic of Belarus No. 149-3of April 302014 r. Available online: http://etalonline.by/ document/?regnum=Hk1400149 (accessed on 14 October 2019).

36. Sereda, E.L. Object of relations on the use and protection of waters in the new Water Code of the Republic of Belarus. J. Belarusian State Univ. Biol. Law 2017, 1, 107-108.

37. The Water Code of Ukraine of June 6, 1995, № 213/95-BP. Available online: http://pravoved.in.ua/sectionkodeks/150-vku.html (accessed on 14 October 2019).

38. Kysykova, G.B. Issues of ownership of water bodies and special water use. Bull. Inst. Legis. Leg. Inf. Repub. Kazakhstan 2010, 3, 82.

39. Yara, O.; Uliutina, O.; Golovko, L.; Andrushchenko, L. The EU Water Framework Directive: Challenges and Prospects for Implementation in Ukraine. Eur. J. Sustain. Dev. 2018, 7, 175-182. [CrossRef]

40. Yatsiuk, M.; Nabyvanets, Y.; Osadcha, N. Adaptation of Ukrainian water resource assessment to European legislation Meteorology Hydrology and Water Management. Res. Oper. Appl. 2017, 5, 37-45. [CrossRef]

41. Water Code of the Republic of Kazakhstan dated July 9, 2003 № 481. Available online: https://zakon.uchet. kz/rus/docs/K030000481_ (accessed on 14 October 2019).

42. Mukasheva, A.A. The system of water legislation: Status and prospects. Bull. Inst. Legis. Leg. Inf. Repub. Kazakhstan 2013, 3, 42-43.

43. Babie, P. Ukraine's Transition from Soviet to Post-Soviet Law: Property as a Lesson in Failed Regulation East/West. J. Ukr. Stud. 2016, 3, 1. [CrossRef]

44. Makhmetova, L.M. Problems of legal regulation of the use and protection of water in the Republic of Kazakhstan. Bull. Inst. Legis. Leg. Inf. Repub. Kazakhstan 2009, 1, 52-53.

45. Zębek, E. Legal protection of waters in the context of human rights. Pol. Nova 2018, 13. [CrossRef]

46. Hering, J.G.; Ingold, K.M. Water Resources Management: What Should Be Integrated? Science 2012, 336, 1234-1235. [CrossRef] [PubMed]

47. Nina, W.; Claudia, S.; Eric, K.-B.; Måns, N. Closing the governance gaps in the water-energy-food nexus: Insights from integrative governance. Glob. Environ. Chang. 2017, 45, 165-173. [CrossRef]

48. Cairns, R.; Krzywoszynska, A. Anatomy of a buzzword: The emergence of 'the water-energy-food nexus' in UK natural resource debates. Environ. Sci. Policy 2016, 64, 164-170. [CrossRef]

49. Pietkiewicz, M. The main directions of EU environmental strategy. In Proceedings of the International Multidisciplinary Scientific GeoConference (SGEM), Surveying Geology \& Mining Ecology Management (SGEM), Sofia. Albena, Bulg. 2017, 17, 395-400.

50. Rahaman, M.M.; Varis, O.; Kajander, T. EU Water Framework Directive vs. Integrated Water Resources Management: The Seven Mismatches. Water Resour. Dev. 2004, 20, 565-575. [CrossRef]

51. Hooper, B.P. Integrated Water Resources Management and River Basin Governance. Water Resour. update 2003, 126, 12-20. 
52. Jeffrey, P.; Gearey, M. Integrated water resources management: Lost on the Road from ambition to realisation? Water Sci. Technol. 2006, 53, 1-8. [CrossRef]

53. Source Integrated Water Resources Management in Action. Wwap, Dhi Water Policy, Unep-dhi Centre for Water and Environment. 2009. Available online: https:/www.gwp.org/globalassets/global/toolbox/ references/iwrm-in-action-unescounwwapunep-dhi-2009.pdf (accessed on 25 October 2019).

54. Integrated Water Resources Management in Eastern Europe, the Caucasus and Central Asia. Available online: https://www.un.org/waterforlifedecade/iwrm.shtml (accessed on 25 October 2019).

55. Radif, A.A. Integrated water resources management (IWRM): An approach to face the challenges of the next century and to avert future crises. Desalination 1999, 124, 145-153. [CrossRef]

56. Liu, Y.; Gupta, H.; Springer, E. Thorsten Wagener Linking science with environmental decision making: Experiences from an integrated modeling approach to supporting sustainable water resources management. Environ. Model. Softw. 2008, 23, 846e858. [CrossRef]

57. Integrated Water Resources Management Global Water Partnership Technical Advisory Committee (TAC). Available online: https://www.gwp.org/globalassets/global/toolbox/publications/background-papers/04integrated-water-resources-management-2000-english.pdf (accessed on 25 October 2019).

58. Antolak, M.; Małkowska, N. Landscape valuation and design process of public space - a case study of the public beach in Mragowo. Acta Sci. Pol. Adm. Locorum 2019, 18, 7-18.

59. Council Directive 98/83/EC of 3 November 1998 on the quality of water intended for human consumption (98/83/EC). Available online: https://eur-lex.europa.eu/legal-content/EN/TXT/?uri=CELEX\%3A31998L0083 (accessed on 25 October 2019).

60. Granit, J.; Lindstrom, A.; Dmitrevsky, V.; Guterstam, B.; Helstrom, M.; Kindler, J.; Kramen, L.; Okruzhko, T.; Paukstis, B.; Smorodinskaya, N.; et al. Management and development of water resources in the Kaliningrad region, Russia, in order to strengthen economic growth and environmentally sustainable development with examples from Lithuania, Poland and Sweden. Stockholm: SIWI Paper 17, June 2011; 26.

61. Khabrieva, Y.; Tikhomirova, Y.A. The Concept of Development of Russian Legislation, Moscow, Russia. 2015, pp. 302-315. Available online: https://izak.ru/upload/iblock/e5f/e5fd12070efc45695d6811c0b891aa64.pdf (accessed on 25 October 2019).

62. Zębek, E. Ochrona strefy brzegowej śródmiejskiego jeziora Jeziorak Mały na tle obowiązujących regulacji prawnych (Protection of the coastal zone of the lake Jeziorak the downtown small compared to existing regulations). Prawo i Środowisko, Nr 4(44), Warszawa. 2005; 123-129. 